Journal of Applied Pharmaceutical Science Vol. 5 (12), pp. 154-158, December, 2015

Available online at http://www.japsonline.com

DOI: $10.7324 / J A P S .2015 .501227$

ISSN 2231-3354 (cc) BY-NC-SA

\title{
Review on Application of Nucleic Acid Amplification Techniques in Pharmaceutical Products Analysis
}

\author{
Mohammad Saleh Al-Aboody* \\ Department of Medical Laboratories, College of Science Al-Zulfi, Majmaah University, Kingdom of Saudi Arabia.
}

\begin{tabular}{|c|c|}
\hline ARTICLE INFO & ABSTRACT \\
\hline Article history: & \multirow{9}{*}{$\begin{array}{l}\text { The aim of this study was to describe application of molecular diagnostic tests based on nucleic acid } \\
\text { amplification technologies (NAATs) in pharmaceutical product analysis. NAAT have become widely established } \\
\text { in clinical microbiology laboratories in recent years, as well as in quality control (QC) laboratories for food } \\
\text { testing, and lately introduced to the pharmaceutical QC laboratories. The number of available nucleic acid and } \\
\text { gene amplification-based rapid microbiological methods has increased over the last few years, and for good } \\
\text { reason. When compare to standard culture based methods, NAAT provide a rapid, an accurate and reliable means } \\
\text { for detecting specific microorganisms of interest, especially in pharmaceutical dosage forms that are required to } \\
\text { be free of objectionable or specified pharmacopeial organisms. This article discussed about the different types of } \\
\text { nucleic acid amplification techniques and methods available to pharmaceutical microbiologists working on } \\
\text { quality control of pharmaceutical products and develop some awareness among other pharmaceutical scientists. } \\
\text { This review also highlights limitations of these methods applied in industrial setup. }\end{array}$} \\
\hline Received on: 19/10/2015 & \\
\hline Revised on: 07/11/2015 & \\
\hline Accepted on: 20/11/2015 & \\
\hline Available online: $27 / 12 / 2015$ & \\
\hline Key words: & \\
\hline Nucleic acid amplification & \\
\hline techniques, Polymerase chain & \\
\hline $\begin{array}{l}\text { reaction, Pharmaceutical } \\
\text { products, rapid methods, }\end{array}$ & \\
\hline & \\
\hline
\end{tabular}

\section{INTRODUCTION}

Deoxyribonucleic acid (DNA) contains the genetic information that controls the development of a microbial cell. DNA determines the genotypic and phenotypic potential of a microbial cell. With the latest advances in genomics, where more than 25 microbial genomes have been sequenced, the potential to use genetic information for the detection and discrimination of microorganisms is endless. Genetic technologies can increase the resolution and specificity of microbial detection and identification in pharmaceutical environments. DNA-based technologies are used in clinical, food, and environmental samples providing valuable information on the survival, distribution and function of microorganisms in those habitats (Hill, 1996; Ieven and Goosens, 1997). One of the technologies based on DNA analysis is the polymerase chain reaction (PCR).It was the first nucleic acid amplification method (NAAT) developed and until now has been the method of choice since its

\footnotetext{
* Corresponding Author

Email:m.alaboudi@mu.edu.sa
}

invention by Mullis (1990). PCR amplifies specific DNA sequences along the microbial genome. For example, a set of DNA primers is used to target the specific sequence to be amplified. The PCR reaction take splace in three different steps such as denaturation, annealing and extension. The three steps are repeated again for a given number of cycles, e.g., 30-35. As soon as the target is amplified, the products are detected by gel electrophoresis. However, new systems have been developed that rely on fluorescence detection of amplified products. PCR based assays are used routinely in the food industry and clinical laboratories to detect and identify bacteria, yeast, and mold (Hill, 1996; Ieven and Goosens, 1997). Now a days, rapid methods are used to detect microbial contamination causing organisms in pharmaceutical products. Microbial Contamination in pharmaceutical products due to the presence of various microorganisms such as (Salmonella spp, Escherichia coli, Pseudomonas aeruginosa, and Staphylococcus aureus)in raw materials and water, or from poor practices during product manufacturing. The presence of microorganisms in pharmaceutical products represents a serious health threat to consumer's worldwide (Underwood, 1998). Furthermore, microbial growth has a negative impact on product integrity (Sutton, 1997). 
On the basis of published scientific studies, the Enterobacteriaceae, Pseudomonas spp., Burkholderia cepacia and mould have been found to be the most common microbial contaminants around the world (Oie and Kamiya, 1996; Zani et al., 1997; Jimenez, 2007). Identification of microbial contaminants provides important information to track contamination sources, implement proper corrective actions and understand microbial community composition (Jimenez, 2004; Cundell, 2006). For this purpose, there are a number of standard methods for identifying and detecting those indicator pathogens in pharmaceutical industry for quality evaluation of raw materials and finished products in different pharmacopoeias. The detection of microbial contaminants has been traditionally performed using cultivation-based methods. However, all these traditional methods of identification based on microbiological culture methods, morphological and biochemical characterization of microorganisms (Baird, 1998).

Therefore, there is a need in pharmaceutical industry to develop and perform a rapid procedure to detect the contaminants in timely manner to take immediate corrective action for contamination control and avoid huge production loss and product integrity. Molecular methodologies such as Adenosine triphosphate (ATP) bioluminescence and polymerase chain reaction (PCR)-based assays provide rapid quality control analysis of cosmetic and pharmaceutical finished products and raw materials. The new molecular methods are available that can rapidly detect microorganisms in contaminated samples.

Hence, in this review to analyze the various nucleic acid techniques available in pharmaceutical product analysis. In addition to that, this review discuss the advantages and issues of implementation of these methods in industrial setup.

\section{VARIOUS MOLECULAR METHODS IN PHARMACEUTICAL PRODUCT ANALYSIS}

During the last five years, several peer review studies have been published on the research, development, validation and application of rapid methods to pharmaceutical microbiology (Samadi et al., 2007; Karanam et al., 2008; Ragheb et al., 2012). ATP bioluminescence, direct viable counts, deoxyribonucleic acid (DNA) and PCR technology have demonstrated that a nonculturable portion of the microbial community in pharmaceutical environments is viable and undetectable by compendial methods. Therefore, these new technologies provide a higher resolution and discrimination between microbial species. The new molecular methods are available that can rapidly detect microorganisms in contaminated samples. ATP bioluminescence and PCR based assays have been developed and validated for rapid microbiological screening of clinical and food samples (Hill, 1996; Ieven and Goosens, 1997). Hugo (1998) reported that ATP is the most important high-energy phosphate compound present in a microbial cell. ATP carries an important function in the microbial cell by providing the energy source to drive microbial viability and growth. ATP bioluminescence technology is based upon the reaction of the enzyme complex luciferase-luciferin, in the presence of oxygen and magnesium, with ATP released from microbial cells resulting in the production of light. Several studies have demonstrated the applicability of ATP bioluminescence to pharmaceutical quality control and it has been previously used as an indicator of microbial viability and biomass in environmental studies (Underwood, 1998). Other studies have reported on the use of ATP bioluminescence assays for determination of the microbial content of different raw materials (De La Rosa, 1995).

Ignar et al. (1998) reported the detection of bacteria, yeast, and mould contamination in pharmaceutical products within 24 to27 hours using the Celsis ATP bioluminescence system (Celsis, Inc., Evanston, IL) and specific enrichment broths. ATP bioluminescence assay provided a 24 hours count of bacteria present in water samples from a reverse osmosis/ ultrafiltration water system, hot water circulating system and cold tap water (Scalici et al., 1998). ATP bioluminescence has also been used for rapid sterility testing of pharmaceutical suspensions and microbial content analysis of finished products (Ignar et al., 1998). However, ATP bioluminescence provides an indication of the total microbial biomass in a product which might be including microbial species whose presence can be acceptable for non-sterile pharmaceuticals. Marino et al. (2000) reported that ATP bioluminescence assays have been used for rapid monitoring of quality in pharmaceutical water systems. Compared with standard methods, which require more than one growth media, the ATP bioluminescence assays were capable of detecting all microorganisms using a single growth medium in a shorter period of time. Drawback of this method is ATP extraction and detection from environmental samples is a labor-intensive and time-consuming procedure.

Several DNA molecular-based technologies are being developed primarily for the characterization of microorganisms (Olson 1998). One such system is Gene-Trak ${ }^{\circledR}$ (Neogen, United States), a hybridization technique used for the identification of specific organisms, even within mixed cultures, by targeting $16 \mathrm{~s}$ or 23s rRNA. Woese (1987) identified 16s RNA as demonstrating phylogenic relationships that could be targeted by labeled DNA probes to identify specific organisms (Stahl et al., 1988). This process is facilitated by the presence of up to $10^{4}$ copies of ribosomal RNA within a cell, although the copy number varies depending upon the metabolic state of the organism. Gene-Trak hybridizes specific DNA probes against the rRNA of the target organism. Approximately $10^{5}-10^{6}$ cells are required to give a positive result; thus some pre-enrichment phase is required. The protocol is generic, however, so the same methodology can be applied to a wide range of microorganisms. The method takes less than 3 hours and requires only minimal equipment. Another advantage is that considerable information is available for the nucleic acid sequences of rRNA, including those of gram-negative organisms. This means that unique DNA probes can be generated for closely related organisms such as E. coli and Salmonella.

Another technique for the isolation and detection of microorganisms from samples is the nucleic acid amplification technologies. PCR is the more familiar technique incorporating the 
enzymatic amplification of target DNA sequences by using a pair of specific primers and a thermotolerant DNA polymerase. In theory PCR provides a rapid, highly sensitive (single-cell detection) and highly specific method for the isolation and enumeration of bacteria yeasts and molds. In practice, about $10^{3}$ organisms/mlL are required to ensure reliable and repeatable amplification (Fung, 1997); thus some pre-enrichment on immunomagnetic concentration may be required (Shaw et al., 1998).

Because the PCR reaction is so efficient, the large amount of amplified DNA may cause cross-contamination problems that result in false positives, so good analytical technique is required. Finally, PCR is an enzymatic reaction, and it is possible that components of the sample may interfere with the amplification (Vaneechoutte and van Eldere, 1997). Inhibition can be overcome by dilution or quenching of the inhibiting components (Kreader, 1996). In this following section discussed about various PCR techniques applied in pharmaceutical product analysis.

\section{NUCLEIC ACID AMPLIFICATION TECHNIQUES (PCR)}

Molecular diagnostic tests based on nucleic acid amplification technologies have become widely established in clinical microbiology laboratories in recent years, as well as in quality control (QC) laboratories for food testing and have been offered lately to the QC laboratories in the pharmaceutical sector (Denoya, 2009). Various authors performed studies on PCR based diagnosis of contaminant identification from pharmaceutical products. In this following section explained in details about various types of methods.

\section{Uniplex PCR}

Uniplex PCR used for the detection of each microorganism individually targeting the conserved region in each bacterial genome. The first PCR application to cosmetics and pharmaceutical quality control has been reported by Jimenez et al. (1998). They used the $\mathrm{BAX}^{\mathrm{TM}}$ system (Dupont Qualicon, Wilmington, DE), a PCR-based assay, S. typhimurium was detected in all 25 samples of pharmaceutical products after a 24 hours enrichment. They reported that rapid methods are faster turnover time than the standard 5 to 6 day detection time. Same author developed and validated PCR based assays to detect all other three USP bacterial indicators, E. coli, $P$. aeruginosa, and $S$. aureus in samples of 24 various pharmaceutical products (Jimenez et al., 1999 and 2000a). They detected in artificially contaminated samples of finished products and raw materials within 27 to 30 hours.

Jimenez and Smalls (2000b) have reported the simplified method with Ready-To-Go PCR beads to detect of B. cepacia inartificially contaminated pharmaceutical samples. Standard methods for isolation and identification of $B$. cepacia require 5 to 6 days to be completed. However, PCR detection of samples contaminated with B. cepacia completed within 27 hours using the Ready-To-Go PCR beads. Apart from the bacterial contamination in pharmaceutical products, detection of mould contamination in finished products require 6 to 8 days to be completed (Anonymous, 2007). Jimenez et al. (1999) developed PCR assay to detect mould contamination (A. niger) in pharmaceutical samples. In that study test was completed within 27 hours while the standard methods required 6-8 days. Yeast contamination, e.g., Candida albicans, was also detected in all the contaminated samples using a PCR-based assay (Jimenez et al., 1998).

Jimenez (2000a) used a PCR-based amplification of conserved ribosomal bacterial sequences $(1.5 \mathrm{~kb})$; it is possible to confirm sterility. All tested samples that were positive by the PCR reaction were also positive by conventional methods. PCR-based assays reduced turn over time from 72 to 24 hours.

Simultaneous PCR detection of bacteria and mould from contaminated cosmetic/pharmaceutical samples was performed using the Stratagene Robocycler 96-Gradient. This new thermocycler allowed the simultaneous amplification of genetic sequences using DNA primers with different annealing temperatures. Low levels of microbial contamination ranging from 1 to 7 CFU were detected (Jimenez, 2001a,b). Samadi et al. (2007) reported PCR based detection of low levels of $S$. aureus contamination in topical lotion pharmaceutical preparations.

Recently Vijayakumar and his co-workers (2011) developed PCR to detect the low levels of $P$. aeruginosa contamination in ophthalmic viscosurgical devices by using universal and specific primers (oprL) to P. aeruoginosa as one of the objectionable microorganisms in pharmaceutical products. Various authors reported uniplex PCR assays listed in table 1.

\section{Multiplex PCR assays}

Multiplex PCR refers to the use of PCR to amplify several different DNA sequences simultaneously (as if performing many separate PCR reactions all together in one reaction). Multiplex PCR assays have been developed and validated for environmental, food and clinical analyses (Mahony et al., 1995; Brasher et al., 1998). So there is need to develop a multiplex assay to amplify all relevant pharmaceutical and cosmetic microbial contaminants in one assay.

Jimenez et al. (2000b) developed PCR analysis for detecting low levels of bacteria and mould contamination in pharmaceutical samples using Ready-To-Go PCR. In this method samples were artificially contaminated with less than $10 \mathrm{CFU}$ of E. coli, S. aureus, $P$. aeruginosa and A. niger. Standard methods required $6-8$ days while PCR method detects the contaminants within 27 hours.

Farajnia et al. (2009) carried out a study on simultaneous detection and identification of four indicator pathogenic bacteria in a single PCR reaction in expectorant syrup. They used specific primers for four objectionable bacteria and their detection time was 27 hours. In India, a study from Hyderabad, Karanam et al. (2008) developed multiplex PCR for detection of indicator pathogens from various raw materials and finished products. 
Table 1: Pharmaceutical products analyzed by uniplex PCR method nucleic acid amplifications by various authors (Sandle and Vijayakumar, 2014)

\begin{tabular}{lcccc}
\multicolumn{1}{c}{ Test products } & PCR for & $\begin{array}{c}\text { Pre-enrichment } \\
\text { step included }\end{array}$ & $\begin{array}{c}\text { PCR } \\
\text { Inhibition }\end{array}$ & Reference \\
\hline $\begin{array}{l}\text { Vee gum, Carboxymethylcellulose Silica, Starch, } \\
\text { Simethicone emulsion, Antiflatulent liquid }\end{array}$ & Salmonella typhimurium & Yes & No & Jimenez et al., (2001a) \\
$\begin{array}{l}\text { Topical lotion } \\
\text { Hydroxypropyl mehtyl cellulose and Sodium Hyaluronate }\end{array}$ & S. aureus & Yes & No & Samadi et al., (2007) \\
\hline
\end{tabular}

Table 2: Pharmaceutical products analyzed by multiplex PCR by various authors (Sandle and Vijayakumar, 2014)

\begin{tabular}{|c|c|c|c|c|}
\hline Test products & PCR for & $\begin{array}{l}\text { Pre-enrichment } \\
\text { step included }\end{array}$ & $\begin{array}{c}\text { PCR } \\
\text { Inhibition }\end{array}$ & Reference \\
\hline $\begin{array}{l}\text { Fluoride dentifrice, Medicated dentifrice, Sleeping tablet, } \\
\text { Antiflatulent liquid, Carboxymethylcellulose, Simethicone and } \\
\text { Lactose }\end{array}$ & $\begin{array}{l}\text { B. cepacia } \\
\text { Bacteria and } \\
\text { Mould }\end{array}$ & Yes & No & Jimenez and Smalls (2000) \\
\hline $\begin{array}{l}\text { Lactose, Nicotinamide, Sodium starch glycollate, Ranitidine } \\
\text { HCL, Mannitol, Ibuprofen suspension }\end{array}$ & $\begin{array}{l}\text { S. aureus, } \\
\text { Salmonella spp. } \\
\text { E. coli } \\
\text { P. aeruginosa }\end{array}$ & Yes & No & Karanam et al., (2008) \\
\hline Expectorant syrup & $\begin{array}{l}\text { S. aureus, } \\
\text { Salmonella spp. } \\
\text { E. coli } \\
\text { P. aeruginosa }\end{array}$ & Yes & No & Farajnia et al., (2009) \\
\hline Different pharmaceutical dosage forms and raw materials & $\begin{array}{l}\text { S. aureus, } \\
\text { Salmonella spp. } \\
\text { E. coli } \\
\text { P. aeruginosa }\end{array}$ & Yes & No & Regheb et al., (2012) \\
\hline
\end{tabular}

In their study, the detection limits for artificial contaminants was $1 \mathrm{CFU} / \mathrm{g}$, whereas in the case of conventional method, the detection limit was $>2 \mathrm{CFU} / \mathrm{g}$. Similarly, when tested with possibly contaminated samples, $35 \%$ was detected for E.coli, Salmonella spp., $S$. aureus and $P$. aeruginosa with multiplex PCR, while only $21 \%$ was detected with standard conventional microbial methods. Recently Regheb and his associates (2012) reported uniplex, duplex and multiplex PCR study for detection of the four main specified microorganisms according to the pharmacopeial recommendations, $E$. coli, $S$. aureus, $P$. aeruginosa, and Salmonella spp. was optimized in different pharmaceutical dosage forms and raw materials. Various authors' reports are listed table.2. Furthermore, the recent advances in DNA microchip technology can lead to specific assays for quality control purposes. DNA microchips have already been used for detecting multiple microbial populations in environmental and clinical samples (Guschin et al., 1997). The same technology might be capable of detecting microbial contaminants in pharmaceutical samples.

\section{ADVANTAGES AND LIMITATIONS}

Rapid detection of objectionable microorganisms results in faster implementation of corrective actions. Detection times using PCR range from 24 to 27 hours. This is a significant reduction when compared to the standard 5 to 7 days detection time. However, drawbacks of these methods are validation and implementation of these new methods are not widely adopted by industry (Jimenez, 2004 and 2007). Some of the major concerns for implementation of PCR-based assays as routine quality control analysis in pharmaceutical laboratories are listed below.

- Absence of validation guidelines

- Uncertain regulatory status
- Lack of validation and technical support

- Lack of understanding of the technologies

- Lack of published scientific studies

- Hesitation from managers and companies to try new methods

- Lack of resources for technology evaluation and implementation

- Systems are expensive

- Underestimation by vendors of regulatory requirements

\section{CONCLUSION}

The goal of this review is to describe the different types of nucleic acid amplification techniques and methods available to pharmaceutical microbiologists working on quality control of pharmaceutical products and develop some awareness among other pharmaceutical scientists. The present review is limited to the validation work published in the peer review scientific literatures. Overall, this article has concluded that rapid methods provide reliable and cost-effective analysis for the microbiological evaluation of pharmaceutical products.

\section{REFERENCES}

Anonymous, 2007. United States Pharmacopeial Convention. The United States Pharmacopeia, $31^{\text {st }}$ Edn.Chapters $\langle 61\rangle,\langle 62\rangle,\langle 1072\rangle$, $<1111\rangle$, <1116> Rockville, MD: United States Pharmacopoeial Convention.

Baird, R., 1998. Pharmaceutical Microbiology, Contamination of non-sterile pharmaceuticals in hospital and community environments In: Hugo, W.B., Russell, A.D., $6^{\text {th }}$ Ed., W.B., Hugo \& A.D., Russell (Eds.), Blackwell science, Oxford, UK. pp. $374-384$.

Brasher, C.W., Depaola, A., Jones, D.D. and Bej, A.K., Detection of microbial pathogens in shellfish with multiplex PCR. Curr Microbiol., 1998;37:101-107. 
Cundell, A.M., Microbial identification strategies in the pharmaceutical industry. PDA J Pharm. Sci. Technol. 2006; 60:111-23.

De La Rosa M.C., Medina, M.R. and Vivar, C., Microbiological quality of pharmaceutical raw materials. Pharm Acta Helv., 1995; 70:227-232.

Farajnia, S., Hassan, M., Nezhadi, S.H., Mohammadnejad, L., Milani, M. and Lotfipour, F., Determination of indicator bacteria in pharmaceutical samples by multiplex PCR. Journal of Rapid Methods \& Automation in Microbiology, 2009; 17:328-338.

Fung D.Y.C. 1997. Overview of rapid method of microbiological analysis. In Food Microbiological Analysis New Technologies Series, no. 12, ed. M.L. Tortorello, and S. M. Gendel, New York: Marcel Dekker, Inc.

Guschin D.Y, Mobarry B.K., Proudnikov D., Stahl, D.A, Rittman, B.E. and Mirzabekov, A.D. Oligonucleotide microchips as genosensors for determinative and environmental studies in microbiology. Appl Environ Microbiol, 1997; 63:2397-2402.

Hill WE. The polymerase chain reaction: application for the detection of foodborne pathogens. Crit Rev Food Sci Nutr 1996; 36:123173.

Hugo, W.B. 1998. Bacteria. In: Hugo WB, Russell AB, eds. Pharmaceutical Microbiology. $6^{\text {th }}$ ed. Oxford, England: Blackwell Science, 3-34.

Ieven M, Goosens H. Relevance of nucleic acid amplification techniques for diagnosis of respiratory tract infections in the clinical laboratory. Clin Microbiol Rev, 1997; 10:242-256.

Ignar, R., English, D., Jimenez, L. Rapid detection of microbial contamination in Triclosan and high fluoride dentifrices using an ATP bioluminescence assay. J Rapid Methods Autom. Microbiol., 1998; 6: 5158.

Jimenez, L., Smalls, S., Scalici, C., Bosko, Y., Ignar, R. and English, D. Detection of Salmonella spp. contamination in raw materials and pharmaceutical products using the $\mathrm{BAX}^{\mathrm{TM}}$ system, a PCR assay. $J$ Rapid Methods Autom Microbiol., 1998; 6:67-76.

Jimenez. L., Smalls, S., Grech, P., Bosko, Y., Ignar, R. and English, D. Molecular detection of bacterial indicators in cosmetic/ pharmaceuticals and raw materials. J Ind Microbiol Biotechnol.,1999;22 (2):93-95.

Jimenez, L., Ignar, R., D'Aiello, R. and Grech, P., Use of PCR analysis for sterility testing in pharmaceutical environments. $J$ Rapid Methods Autom Microbiol., 2000 a; 8: 11-20.

Jimenz, L., Smalls, S. and Ignar, R. Use of PCR analysis for detecting low levels of bacteria and mold contamination in pharmaceutical samples, Journal of Microbiological Methods., 2000 b; 41(3):259-65.

Jimenez, L., Scalici, C., Smalls, S, Bosko, Y.and Ignar, R., PCR Detection of Salmonella typhimurium in Pharmaceutical Raw Materials and Products Contaminated with a Mixed Bacterial Culture Using the BAX ${ }^{\mathrm{TM}}$ System PDA Journal of Pharmaceutical Science and Technology,2001 a; 55(5):286 - 289

Jimenez, L. Simultaneous PCR detection of bacteria and mold DNA sequences in pharmaceutical samples by using a gradient thermocycler. J Rapid Methods Autom Microbiol., 2001 b;9: 263-270.

Jimenez, L., 2004. Microbial Contamination Control in the Pharmaceutical Industry. $1^{\text {st }}$ edn. New York: Marcel Dekker.

Jimenez, L.. Microbial Diversity in Pharmaceutical Product Recalls and Environments. PDA Journal of Pharmaceutical Science and Technology, 2007; 61;383 - 399.

Karanam, V.R., Reddy, H.P., Subba Raju, B.V., Rao, J.C., Kavikishore, P.B. and Vijayalakshmi, M. Detection of indicator pathogens from pharmaceutical finished products and raw materials using multiplex PCR and comparison with conventional microbiological methods. Journal of Industrial microbiology and Biotechnology, 2008; 35(9):1007 18.

Kreader, C.A. Relief of amplification inhibition in PCR with bovine serum albumin or T4 gene 32 protein. Applied and Environmental Microbiology 1996;62:1102-1106.

Mahony, J.B., Luinstra, K.E., Tyndall, M., Sellors, J.W., Krepel, J. and Chernesky, M. Multiplex PCR for detection of Chlamydia trachomatis and Nesseria gonorrhoeae in genitourinary specimens. J Clin Microbiol.,1995;33:3049-3053

Marino, G., Maier, C. and Cundell, A.M. A comparison of the MicroCount Digital System to plate count and membrane filtration methods for the enumeration of microorganisms in water for pharmaceutical purposes. PDA J Pharm Sci Technol.,2000;54:172-192.

Mullis K.B. The unusual origin of the polymerase chain reaction. Sci Am. 1990;262:56-61, 64

Oie, S. and Kamiya A. Microbial contamination of antiseptics and disinfectants. AmJ Infect Control., 1996;24:389-395.

Olson, W.P. 1996. Gas chromatography, substrate utilization, and systems for microbial identification. In Automated Microbial Identification and Quantitation, ed. W.P.Olson. Buffalo Grove, Ill: Interpharm

Ragheb S,M., Yassin A.S., Amin M.A.,The application of uniplex, duplex, and multiplex PCR for the absence of specified microorganism testing of pharmaceutical excipients and drug products. PDA J Pharm Sci Technol, 2012;66(4):307-17.

Samadi, N., Alvandi, M., Fazeli, M.R., Azizi, E,, Mehrgan, H. and Naseri M. PCR based detection of Low levels of Staphylococcus aureus contamination in Pharmaceutical Preparations, Journal of Bio Sciences, 2007; 7(2), $359-363$.

Sandle, T. Vijayakumar, R. 2014.,Cleanroom Microbiology, Chapter - 7, Characterization and identification of cleanroom microflora, Davis Healthcare International Publishing, LLC.,/PDA: Bethesda, MD, USA $221-225$.

Scalici, C., Smalls, S., Blumberg, S., English, D. and Jimenez, L. Comparison of Millipore Digital Total Count System and standard membrane filtration procedure to enumerate microorganisms in water samples from cosmetic/pharmaceutical environments. J Rapid Methods Autom Microbiol., 1998; 7:199-209.

Shaw, S.J., Blais B.W., and D.C.Nundy. Performance of the Dynabeads anti-Salmonella system in the detection of Salmonella species in foods, animal feeds and environmental samples. Journal of Food Protection., 1998:61:1507-1510.

Stahl, D.A.,Flesher. B., Mansfield H.R., and Montgomery.L. Use of phylogenetically based hybridization probes for studies of ruminal microbial ecology. Applied and Environmental Microbiology, 1998; 54:1079-1084.

Sutton, S.V.W., Magee, M.A., and Brannan, D.K. 1997., Cosmetic Microbiology, A Practical Handbook, D.K. Brannan (Ed.), CRC Press, New York, NY, pp $96-122$

Underwood, E. 1998. Ecology of microorganisms as its affects the pharmaceutical industry. In: Pharmaceutical Microbiology, $6^{\text {th }}$ edition. Hugo WB, Russel AB, Eds. Oxford, UK: Blackwell Science, pp.339-354.

Vaneechoutte, M., and Van Eldere. J. The possibilities and limitations of nucleic acid amplification technology in diagnostic microbiology. Journal of Medical Microbiology 1997; 46:188-194.

Vijayakumar, R., Kannan.V.V. and Manoharan, C., Molecular Diagnosis of Pseudomonas aeruginosa contamination in ophthalmic viscosurgical devices. International Journal of Research in Pharmaceutical Sciences, 2011; 2(4), 579 - 584.

Woese, C.R. Bacterial evolution. Microbiological Reviews, 1987;51:221-271

Zani, F., Minutello, A., Maggi, L., Santi, P., and Mazza, P. Evaluation of preservative effectiveness in pharmaceutical products: The use of a wild strain of Pseudomonas cepacia. J. Appl. Microbiol. 1997; 83, $322-326$.

\section{How to cite this article:}

Mohammad Saleh Al-Aboody. Review on Application of Nucleic Acid Amplification Techniques in Pharmaceutical Products Analysis. J App Pharm Sci, 2015; 5 (12): 154-158. 